\title{
Torrefaction Thermogravimetric Analysis and Kinetics of Sorghum Distilled Residue for Sustainable Fuel Production
}

\author{
Shih-Wei Yen ${ }^{1}$, Wei-Hsin Chen ${ }^{2,3,4, * \mathbb{D}}$, Jo-Shu Chang ${ }^{1,3,5, *}$, Chun-Fong Eng ${ }^{2}$, Salman Raza Naqvi ${ }^{6} \mathbb{D}$ \\ and Pau Loke Show ${ }^{7}$ (D)
}

1 Department of Chemical Engineering, National Cheng Kung University, Tainan 701, Taiwan; n38071029@ncku.edu.tw

2 Department of Aeronautics and Astronautics, National Cheng Kung University, Tainan 701, Taiwan; ecfong94@gmail.com

3 Research Center for Smart Sustainable Circular Economy, Tunghai University, Taichung 407, Taiwan

4 Department of Mechanical Engineering, National Chin-Yi University of Technology, Taichung 411, Taiwan

5 Department of Chemical and Materials Engineering, College of Engineering, Tunghai University, Taichung 407, Taiwan

6 School of Chemical and Materials Engineering (SCME), National University of Sciences and Technology (NUST), H-12, Islamabad 44000, Pakistan; salman.raza@scme.nust.edu.pk

7 Department of Chemical and Environmental Engineering, Faculty of Science and Engineering, University of Nottingham Malaysia, Semenyih 43500, Selangor Darul Ehsan, Malaysia;

PauLoke.Show@nottingham.edu.my

* Correspondence: chenwh@mail.ncku.edu.tw (W.-H.C); changjs@mail.ncku.edu.tw (J.-S.C.)

Citation: Yen, S.-W.; Chen, W.-H.; Chang, J.-S.; Eng, C.-F.; Raza Naqvi, S.; Show, P.L. Torrefaction

Thermogravimetric Analysis and Kinetics of Sorghum Distilled Residue for Sustainable Fuel Production. Sustainability 2021, 13, 4246. https:// doi.org/10.3390/su13084246

Academic Editor: Algirdas Jasinskas

Received: 15 March 2021

Accepted: 7 April 2021

Published: 11 April 2021

Publisher's Note: MDPI stays neutral with regard to jurisdictional claims in published maps and institutional affiliations.

Copyright: (c) 2021 by the authors. Licensee MDPI, Basel, Switzerland. This article is an open access article distributed under the terms and conditions of the Creative Commons Attribution (CC BY) license (https:// creativecommons.org/licenses/by/ $4.0 /)$.
Abstract: This study investigated the kinetics of isothermal torrefaction of sorghum distilled residue (SDR), the main byproduct of the sorghum liquor-making process. The samples chosen were torrefied isothermally at five different temperatures under a nitrogen atmosphere in a thermogravimetric analyzer. Afterward, two different kinetic methods, the traditional model-free approach, and a two-step parallel reaction (TPR) kinetic model, were used to obtain the torrefaction kinetics of SDR. With the acquired $92-97 \%$ fit quality, which is the degree of similarity between calculated and real torrefaction curves, the traditional method approached using the Arrhenius equation showed a poor ability on kinetics prediction, whereas the TPR kinetic model optimized by the particle swarm optimization (PSO) algorithm showed that all the fit qualities are as high as $99 \%$. The results suggest that PSO can simulate the actual torrefaction kinetics more accurately than the traditional kinetics approach. Moreover, the PSO method can be further employed for simulating the weight changes of reaction intermediates throughout the process. This computational method could be used as a powerful tool for industrial design and optimization in the biochar manufacturing process.

Keywords: sorghum distilled residue; thermogravimetric analysis; torrefaction kinetics; biomass and bioenergy; particle swarm optimization (PSO); biochar

\section{Introduction}

Since the mid-20th century, the prosperous growth of human economic activities has caused a significant increase in greenhouse gas (GHG) emissions. The greenhouse effect continues to drive up the global average temperature rapidly, causing global warming and climate change simultaneously. These strong counterattacks from Mother Nature have badly been affecting human civilization and development. Therefore, reducing carbon emissions has become an urgent issue and critical action. Renewable energy, including biochar, is regarded as one of the sustainable and clean energies that can gradually replace traditional fossil fuels.

With the advantages of high heating value and great combustion quality as solid fuel, biochar has been widely used as bioenergy and biofuel [1]. It is an important part of renew- 
able energy and is regarded as one of the alternatives to fossil fuels [2]. Compared with traditional coal fuels, biochar is a new generation of environmentally sustainable energy.

Reviewing the research literature on biochar, there are many types of sources that have been used as feedstocks, including algae, crops, forest waste, etc. [1,3-11]. However, there is hardly any research on SDR upgrades by torrefaction [11]. Sorghum liquor, also known as Baijiu, is the most consumed spirit in the world. While producing more than 10 billion liters of sorghum liquor annually, it also produces more than 66.1 billion $\mathrm{kg}$ of distilled residue, SDR, every year. This by-product is usually processed into animal feed. However, owing to oversupply, it is not easy to dispose of all of it, so the price is inevitably low. SDR also causes environmental hygiene problems. In the application of SDR for bioenergy, there are many studies related to microbial fermentation in the literature. For example, distilled grain waste (DGW, i.e., SDR) can be converted into biogas through anaerobic fermentation by methanogen or anaerobic microorganisms [12,13]. In addition, Saccharomyces cerevisiae can be used to ferment sorghum liquor waste (or SDR) to produce bioethanol [14]. In terms of thermochemical research, Ye et al. [15] evaluated the potential of pyrolysis on converting Baijiu Diuzao (Chinese liquor industry waste, i.e., SDR) into bioenergy for the first time and used the artificial neural networks (ANN) model to validate the pyrolytic behavior. The research results showed that the temperature between $130^{\circ} \mathrm{C}$ and $373^{\circ} \mathrm{C}$ would be the best condition for converting SDR into chemicals and energy. This study aims at evaluating two different kinetic approaches to the torrefaction process of SDR and trying to determine its process parameters, which could provide useful references for the SDR-biochar industry in the future.

Pyrolysis is a kind of thermal decomposition reaction in an oxygen-deficient or inert gas environment. The reaction temperature varies with the material being used, roughly between $200-1200{ }^{\circ} \mathrm{C}$. It is widely used in the industry to produce carbon black, syngas, pyroligneous acid, or biofuels such as biodiesel. Torrefaction, which has been called mild pyrolysis [16], is a thermal treatment technology in a relatively low-temperature range of $200-300{ }^{\circ} \mathrm{C}[1,2,10,17]$, being carried out in an inert gas environment or oxygen-deficient atmosphere, which aims to upgrade biomass to a homogeneous and hydrophobic biofuel with increased energy density [6], heating value, better grindability, and superior combustion characteristics [2,16,18-21]. In this study, SDR was chosen as a cheap feedstock to carry out the torrefaction process at five different temperatures isothermally in a thermogravimetric analyzer under an inert gas environment. The torrefaction severity index (TSI) chart [3], a unique three-dimensional profile that depicts the relationship between the degree of thermal decomposition, torrefaction time, and temperature, could be a practical tool for providing the process parameters of torrefaction.

Simply speaking, there are two approaches to study the weight loss kinetics, according to the presence or absence of its reaction kinetic model, namely the model-free method [3] and the model-based method $[6,18]$. The first method does not need any model to find the thermal decomposition reaction rate equation of SDR and various parameters applicable throughout the range from 200 to $300{ }^{\circ} \mathrm{C}$. In the second approach, usually, a two-step reaction kinetic model is used with artificial intelligence method, e.g., particle swarm optimization (PSO) to simulate the weight loss curves of real torrefaction and the kinetic parameters, as well as each fit quality [22], which is a degree of similarity between simulation and real torrefaction curve. Reviewing the literature, PSO has been used for the prediction of thermal decomposition kinetics of a variety of biomass materials, including wood, microalgae, crops, and forest waste. A two-step parallel reaction (TPR) model was coupled with PSO for simulating the behavior of pyrolysis or torrefaction $[6,18,22]$. As mentioned above, only Ye et al. [15] used ANN to study the pyrolysis behavior of SDR for the first time. However, the kinetics of torrefaction reaction using SDR as biomass has not been discussed in depth. Therefore, in addition, to using PSO to optimize the torrefaction kinetics of SDR for the first time, this research also compared and evaluated the traditional model-free method with the model-based PSO method, which can provide us with more inspiration when studying torrefaction kinetics of SDR. 
The evolutionary algorithm (EA) is a subset of evolutionary computation (EC) in artificial intelligence (AI). It has successively developed various technologies, to name a few, including genetic algorithm (GA), differential evolution (DE), ant colony optimization (ACO), and particle swarm optimization (PSO). PSO is a well-regarded, simple but powerful technique to optimize the pyrolysis kinetics of microalgae [22]. In this study, to achieve global optimization, PSO was used to simulate the isothermal torrefaction kinetics of SDR. For further evaluating the traditional model-free method and the evolutionary algorithm PSO, the fit qualities of the two methods were calculated to compare the degree of similarity between predicted and actual torrefaction kinetics.

\section{Materials and Methods}

\subsection{Materials}

Sorghum distilled residue (SDR) was the raw material selected for this study. It is a by-product of the liquor production process in a distillery located in southern Taiwan. SDR was ground into powder after drying at $105^{\circ} \mathrm{C}$ for $6 \mathrm{~h}$ and stored in a dry-keeper until performing the thermogravimetric analysis (TGA). The analyses of various basic properties are detailed in Table 1. The proximate analysis was based on the standard procedure of the American Society for Testing and Materials. The content of crude carbohydrate, crude protein, and crude lipid in the sample was obtained by the phenol-sulfuric acid method, Kjeldahl method, and Soxhlet-extract method, respectively. The calorific value was measured by a bomb calorimeter (IKA C5000).

Table 1. Basic properties of sorghum distilled residue (SDR).

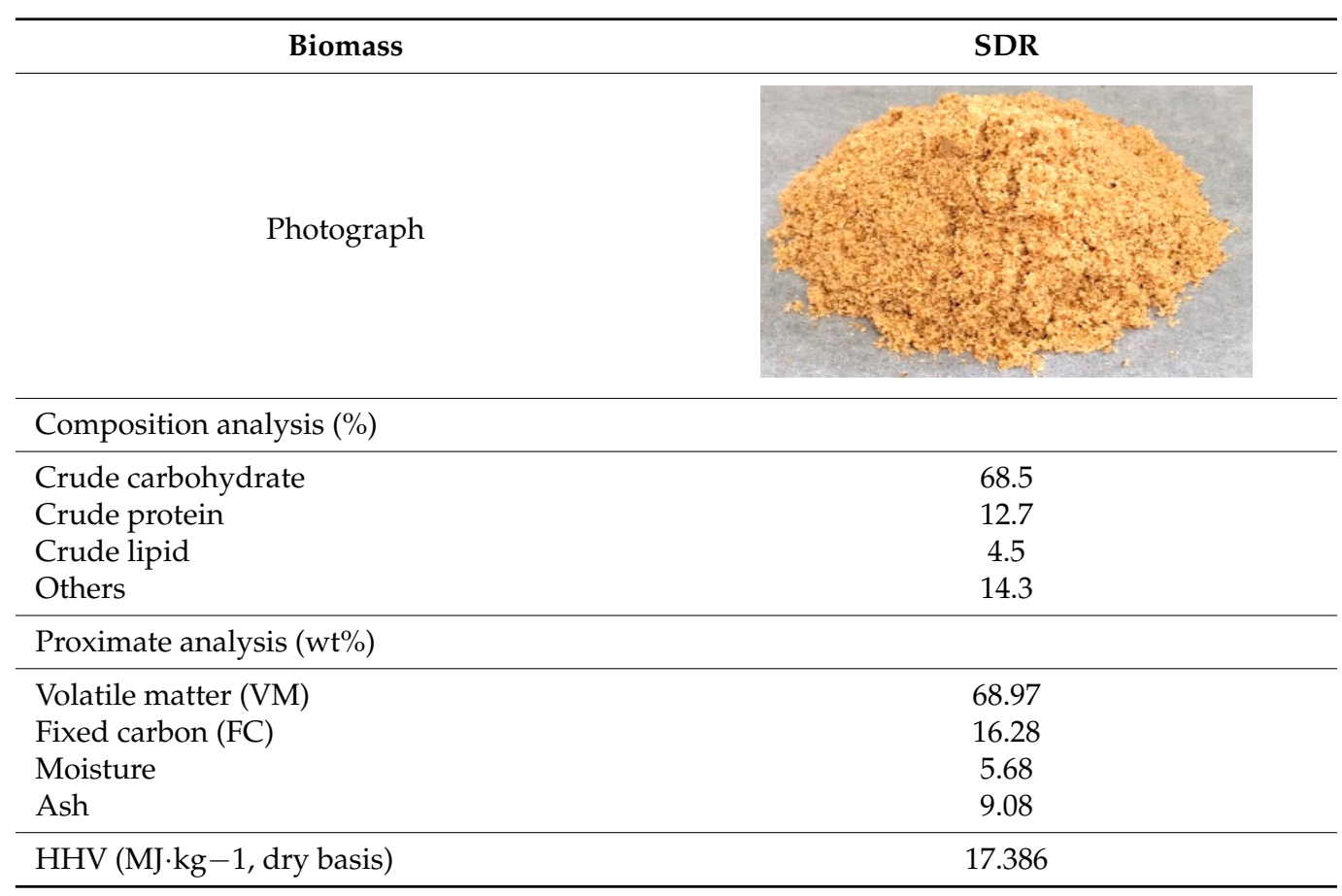

\subsection{Thermogravimetric Analysis}

A thermogravimetric analyzer was used to analyze the SDR pyrolysis and torrefaction characteristics and the torrefaction kinetics was conducted accordingly. Each time about $5 \mathrm{mg}$ of the biomass powder was weighed and loaded inside an aluminum crucible. Sample weight was continuously measured under a nitrogen flow rate of $100 \mathrm{~mL} / \mathrm{min}$. The sample was first heated from room temperature to $105^{\circ} \mathrm{C}$ at a heating rate of $20{ }^{\circ} \mathrm{C} / \mathrm{min}$ and then held at $105^{\circ} \mathrm{C}$ for $10 \mathrm{~min}$ to remove moisture. After that, the temperature was further increased to $850{ }^{\circ} \mathrm{C}$ at a heating rate of $20^{\circ} \mathrm{C} / \mathrm{min}$. In this way, the distribution curves of 
TGA and DTG were obtained to understand the characteristics of the biomass throughout the whole pyrolysis process.

In the isothermal torrefaction experiment, the samples were heated from room temperature to $105^{\circ} \mathrm{C}$ at a heating rate of $20^{\circ} \mathrm{C} / \mathrm{min}$ and then held up at $105^{\circ} \mathrm{C}$ for $10 \mathrm{~min}$ for moisture removal. Next, they were further heated to 5 different temperatures at the same heating rate of $20^{\circ} \mathrm{C} / \mathrm{min}$; they were $200{ }^{\circ} \mathrm{C}, 225^{\circ} \mathrm{C}, 250{ }^{\circ} \mathrm{C}, 275{ }^{\circ} \mathrm{C}$, and $300{ }^{\circ} \mathrm{C}$ and then subjected to isothermal torrefaction at these temperatures for $60 \mathrm{~min}$, followed by heating to $850{ }^{\circ} \mathrm{C}$ at a heating rate of $20^{\circ} \mathrm{C} / \mathrm{min}$ to end the experiments. To ensure a high degree of both accuracy and precision of the experimental data, a thermogravimetric analyzer is regularly calibrated. Each of the same experimental conditions was carried out more than twice to confirm the excellent reproducibility. The relative error was controlled within $3 \%$ for the TGA measurement.

\subsection{Isothermal Torrefaction Kinetics}

Equation (1) is the kinetic modeling equation [5,23]. This formula can be used to macroscopically express the rate of thermal degradation to study the isothermal torrefaction kinetics.

$$
\frac{\mathrm{dC}}{\mathrm{dt}}=\mathrm{k}(1-\mathrm{C})^{\mathrm{n}}
$$

where $\mathrm{C}$ is the conversion of the sample, $\mathrm{k}$ is the reaction rate constant and $\mathrm{n}$ is the reaction order. The conversion $\mathrm{C}$ can be defined as

$$
\mathrm{C}=\frac{\mathrm{W}_{\mathrm{i}}-\mathrm{W}}{\mathrm{W}_{\mathrm{i}}-\mathrm{W}_{\mathrm{f}}}
$$

where $\mathrm{W}, \mathrm{W}_{\mathrm{i}}, \mathrm{W}_{\mathrm{f}}$ are the instant sample weight, initial sample weight, and final sample weight, respectively. In this study, $\mathrm{W}_{\mathrm{i}}$ represents the weight of SDR after removing moisture at $105^{\circ} \mathrm{C}$ for $10 \mathrm{~min}$ and $\mathrm{W}_{\mathrm{f}}$ represents the weight of SDR at the final temperature of $800{ }^{\circ} \mathrm{C}$. In the process of isothermal torrefaction, the relationship between conversion and heating time is expressed as [24]

$$
\left\{\begin{array}{c}
\ln \left(\frac{1-\mathrm{C}_{0}}{1-\mathrm{C}}\right)=\mathrm{k}\left(\mathrm{t}-\mathrm{t}_{0}\right) \quad \text { if } \mathrm{n}=1 \\
(1-\mathrm{C})^{1-\mathrm{n}}-\left(1-\mathrm{C}_{0}\right)^{1-\mathrm{n}}=\mathrm{k}(\mathrm{n}-1)\left(\mathrm{t}-\mathrm{t}_{0}\right) \text { if } n \neq 1
\end{array}\right.
$$

where $\mathrm{C}_{0}$ is the conversion at the onset $\left(\mathrm{t}=\mathrm{t}_{0}\right)$ of isothermal torrefaction. In Equation (3), when $\mathrm{n}=1$, which means that the thermal degradation is a first-order reaction, by plotting $\ln (1-\mathrm{C})-1$ versus heating time $\left(\mathrm{t}-\mathrm{t}_{0}\right)$, a straight line can be obtained and the slope of this straight line will be the reaction rate constant $k$, while $n \neq 1$, the plot of $(1-C) 1-n$ versus torrefaction time $t$ gives a straight line with a slope of $(n-1) k$. Therefore, regardless of which situation it is in, by processing the data from torrefaction experiments via Equations (2) and (3), the reaction rate constant $k$ can be obtained.

To further discuss the reaction rate constant $k$, assuming that the torrefaction reaction obeys the Arrhenius equation (Equation (4)), which shows that the chemical rate constant varies as a negative exponential of the reciprocal absolute temperature.

$$
k=\operatorname{Aexp}\left(-\frac{E a}{R T}\right)
$$

where $\mathrm{A}$ is the pre-exponential factor, Ea is the activation energy, $\mathrm{R}$ is the universal gas constant and T stands for the absolute temperature (in kelvins). Taking the logarithm of both sides in Equation (4) to get the following Equation (5).

$$
\ln \mathrm{k}=\ln \mathrm{A}-\frac{\mathrm{Ea}}{\mathrm{RT}}
$$


Through the aforementioned approach, five reaction rate constants at different temperatures can be obtained. Furthermore, by plotting $\ln (\mathrm{k})$ versus $1 / \mathrm{T}$, a straight line can be obtained with a slope of $-\mathrm{Ea} / \mathrm{R}$ and an intercept of $\ln \mathrm{A}$. Therefore, two important constants, Ea and A, applicable to $200-300{ }^{\circ} \mathrm{C}$ can be obtained. Finally, the equation of the thermal degradation conversion in the temperature range of $200-300{ }^{\circ} \mathrm{C}$ can be obtained and it can be used to describe the actual weight loss curves of SDR in the process of torrefaction.

\subsection{Two-Step Reaction Mechanism}

Prins et al. [6] used a two-step reaction mechanism to simulate the kinetics of torrefaction (as given in Equation (6)). First, reactant $\mathrm{A}$ is converted into intermediate I and the volatiles $V_{1}$, and intermediate $I$ is further converted into the final product $B$ and the volatiles $\mathrm{V}_{2}$.

$$
\begin{array}{cc}
\mathrm{k}_{\mathrm{V} 1} \mathrm{~V}_{1} & \mathrm{k}_{\mathrm{V} 2} \mathrm{~V}^{\mathrm{V}_{2}} \\
\mathrm{k}_{1} & \mathrm{I} \underset{\mathrm{k}}{\rightarrow} \mathrm{B}
\end{array}
$$

where $\mathrm{k}_{1}, \mathrm{k}_{\mathrm{V} 1}, \mathrm{k}_{2}, \mathrm{k}_{\mathrm{V} 2}$, respectively, represent four reaction rate constants.

Assuming that all reactions obey first-order kinetics, the differential rate equations for each of the components are given by Equations (7)-(11)

$$
\begin{gathered}
\frac{\mathrm{dW}}{\mathrm{dt}}=-\left(\mathrm{k}_{1}+\mathrm{k}_{\mathrm{V} 1}\right) \mathrm{W}_{\mathrm{A}} \\
\frac{\mathrm{dW}_{\mathrm{I}}}{\mathrm{dt}}=\mathrm{k}_{1} \mathrm{~W}_{\mathrm{A}}-\left(\mathrm{k}_{2}+\mathrm{k}_{\mathrm{V} 2}\right) \mathrm{W}_{\mathrm{I}} \\
\frac{\mathrm{dW} \mathrm{B}}{\mathrm{dt}}=\mathrm{k}_{2} \mathrm{~W}_{\mathrm{I}} \\
\frac{\mathrm{dW} \mathrm{V} 1}{\mathrm{dt}}=\mathrm{k}_{\mathrm{V} 1} \mathrm{~W}_{\mathrm{A}} \\
\frac{\mathrm{dW} \mathrm{V} 2}{\mathrm{dt}}=\mathrm{k}_{\mathrm{V} 2} \mathrm{~W}_{\mathrm{I}}
\end{gathered}
$$

where $\mathrm{W}_{\mathrm{X}}$ is the weight of component $\mathrm{X}(\mathrm{X}=\mathrm{A}, \mathrm{I}, \mathrm{B}, \mathrm{V} 1, \mathrm{~V} 2)$.

\subsection{Particle Swarm Optimization (PSO)}

In Section 2.3, the Arrhenius equation was adopted to study the kinetics in the torrefaction process. It assumes that the two important factors in the Arrhenius equation, Ea and A, are temperature-independent constants. In reality, though, Ea and A are dependent on temperature. Therefore, if the "temperature range is large", the Arrhenius equation is not suitable for describing the kinetics of chemical reaction without being modified. In addition to the Arrhenius equation, many other phenomenological formulas about activation energy have been proposed. For example, the deformed Arrhenius equation (DAE), generalized Mott law (GML), modified Arrhenius equation (MAE) and curved Arrhenius plot (CAP) all appropriately describe how Ea varies with temperature [25]. Nevertheless, the Chi-square Test and coefficient of determination found that these corrections still cannot accurately describe the real torrefaction behavior [25]. In summary, in Section 2.3, the set of Ea and A obtained in the temperature range $\left(200-300^{\circ} \mathrm{C}\right)$ may not accurately describe the kinetics at each isothermal torrefaction temperature. Therefore, a more precise approach is needed and the evolutionary algorithm can be used to simulate the kinetics of these five different isothermal torrefaction temperatures. The torrefaction temperatures in the simulation are not a range but five fixed values and the simulated weight loss curve of each group may be more in line with the actual weight loss curve. 
In this section, momentum-type PSO [26] is applied to achieve global optimization and the equation is given by Equations (12) and (13).

$$
\begin{gathered}
\overrightarrow{\mathrm{v}}_{\mathrm{i}}^{\mathrm{k}+1}=\beta_{\mathrm{c}} \times \Delta \overrightarrow{\mathrm{v}}_{\mathrm{i}}^{\mathrm{k}+1}+\varphi_{1} \operatorname{rand}()\left(\text { pbest }_{\mathrm{i}}-\overrightarrow{\mathrm{x}}_{\mathrm{i}}^{\mathrm{k}}\right)+\varphi_{2} \operatorname{rand}()\left(\text { gbest }-\overrightarrow{\mathrm{x}}_{\mathrm{i}}^{\mathrm{k}}\right) \\
\overrightarrow{\mathrm{x}}_{\mathrm{i}}^{\mathrm{k}+1}=\overrightarrow{\mathrm{x}}_{\mathrm{i}}^{\mathrm{k}}+\alpha_{\mathrm{c}} \times \overrightarrow{\mathrm{x}}_{\mathrm{i}}^{\mathrm{k}+1}, \mathrm{i}=1,2, \ldots, \mathrm{N}_{\text {particle }}
\end{gathered}
$$

where $v_{i}$ is the velocity of the $i$-th particle, $x_{i}$ is the position of the $i$-th particle; $\alpha_{C}, \beta_{C}$ are momentum constants; $\varphi_{1}$ and $\varphi_{2}$ are cognitive learning rate and social learning rate, respectively; rand () is a random number in the range of $[0,1]$; pbest $_{i}$ is the best position of the $\mathrm{i}$-th particle; gbest is the global best position; $\mathrm{N}_{\text {particle }}$ is the number of particles searching for the optimal solution.

To predict the weight loss curve, the least-squares method is applied and the target function (TAR) to be calculated is given by Equation (14)

$$
\operatorname{TAR}^{\mathrm{T}}=\sum_{\mathrm{j}}\left(\mathrm{W}_{\mathrm{j}, \exp }^{\mathrm{T}}-\mathrm{W}_{\mathrm{j}, \text { cal }}^{\mathrm{T}}\right)^{2}
$$

where $\mathrm{T}$ is the temperature at which the isothermal torrefaction take place; $\mathrm{W}_{\mathrm{j}, \text { exp }}^{\mathrm{T}}$ is the experimental sample weight of the $j$-th datum at a certain reaction temperature; $\mathrm{W}_{\mathrm{j} \text {, cal }}^{\mathrm{T}}$ is the calculated sample weight of the $j$-th datum at a certain reaction temperature.

The flowchart of the PSO algorithm is shown in Figure 1. In addition, the fit quality (F) shown below is used to indicate the similarity between the calculated weight loss curve and the actual weight loss curve (Equation (15)). The PSO algorithm in this study was compiled with the Fortran programming language. First, a set of rough values, Ea and A, must be chosen simply based on relevant literature. If Ea and A were given appropriately at the beginning, it may reduce the number of iterations and have a better chance to converge. After initializing them, the program continues to process them with formulas to obtain the TAR and F values and then update a set of speed and position values of particles based on this result. Afterward, the PSO algorithm repeats the iterative cycle until the optimized criterion is met. In this study, the criterion is that TAR is smaller than $10^{-5}$. When the criterion is met the iteration stops and Ea and A converge as the globally best values, so the fit quality can also be found. In the process of optimizing Ea and A values, i.e., particles, the velocity and position of particle $i$ determine the position of the next particle $i+1$, which is the value of the next set of Ea and A.

$$
\mathrm{F}(\%)=\left[1-\frac{\sqrt{\frac{\text { TAR }}{\mathrm{N}}}}{\left(\mathrm{W}_{\exp }\right)_{\max }}\right] \times 100 \% .
$$

where $\left(\mathrm{W}_{\text {exp }}\right)_{\max }$ is the maximum sample weight in the experiment. 


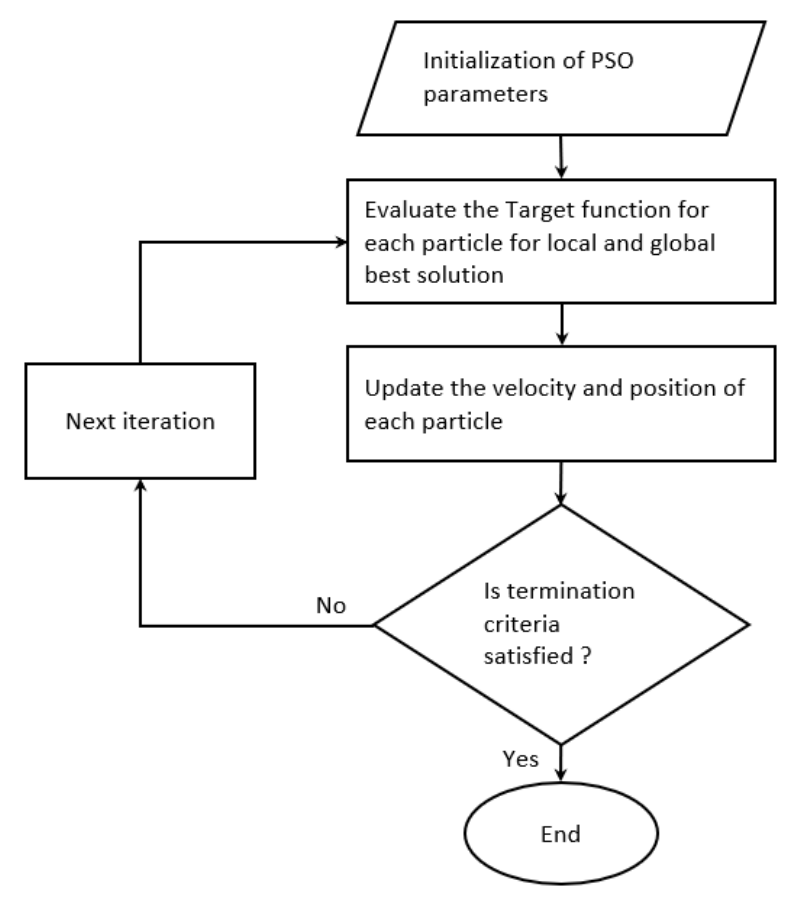

Figure 1. Flowchart of particle swarm optimization (PSO) algorithm.

\section{Results and Discussion}

\subsection{Basic Properties and Thermogravimetric Analysis}

Excluding other components from the results of the composition analysis in Table 1, the composition could be arranged in descending order according to the amount of content and gives that carbohydrate $>$ protein $>$ lipid. It is speculated that the biggest chunk of the composition is derived from the starch in the endosperm of the sorghum grain. Surprisingly, after the fermentation process of the liquor production, a large amount of starch remains in the SDR without being utilized by the microorganisms. In the approximate analysis, the volatile matter is as high as $68.97 \%$, indicating that the reactivity of the SDR is high [3]. The content of ash in the residue is $9.08 \%$ by weight. From the perspective of gasification, the slagging phenomenon in the gasifier can be reduced by blending the residues with coal [3].

The thermogravimetric analysis (TGA) and derivative thermogravimetric (DTG) analysis of SDR are plotted in Figure 2. The whole pyrolysis process can be roughly divided into 4 stages. Dehydration is the first stage $\left(25-200^{\circ} \mathrm{C}\right)$, the second stage is the decomposition of proteins and carbohydrates $\left(200-350^{\circ} \mathrm{C}\right)[3,27]$, the third stage is the decomposition of lipids $\left(350-550{ }^{\circ} \mathrm{C}\right)[3,8]$ and, finally, the fourth stage is the decomposition of other components $\left(550-800^{\circ} \mathrm{C}\right)$. Hardly any weight change occurs after $800^{\circ} \mathrm{C}$. Obviously, the sample weight drops drastically in the second stage and the DTG curve shows the fastest thermal decomposition rate at $317^{\circ} \mathrm{C}$. It is known from Table 1 that the total content of carbohydrates and proteins exceeds $80 \%$; thus, the depolymerization, decarboxylation, and cracking reactions $[28,29]$ of carbohydrates and proteins [27] dominate the entire pyrolysis process of SDR.

\subsection{Isothermal Torrefaction}

The curves of TGA and heating temperature throughout the entire SDR pyrolysis process are shown in Figure 3. In the temperature holding interval, the two curves of 200 and $225{ }^{\circ} \mathrm{C}$ almost overlap, as a consequence of light torrefaction [3] and the heating time almost does not affect the thermal decomposition of SDR. On the contrary, when torrefying at $300{ }^{\circ} \mathrm{C}$, most of the carbohydrates and proteins in SDR decompose severely and cause the sample weight to fall to a large extent at the beginning and then after about $10 \mathrm{~min}$, the sample weight decreases much slightly. In the middle torrefaction temperatures of 250 and $275^{\circ} \mathrm{C}$, the weight loss gradually increases with the torrefaction time. 


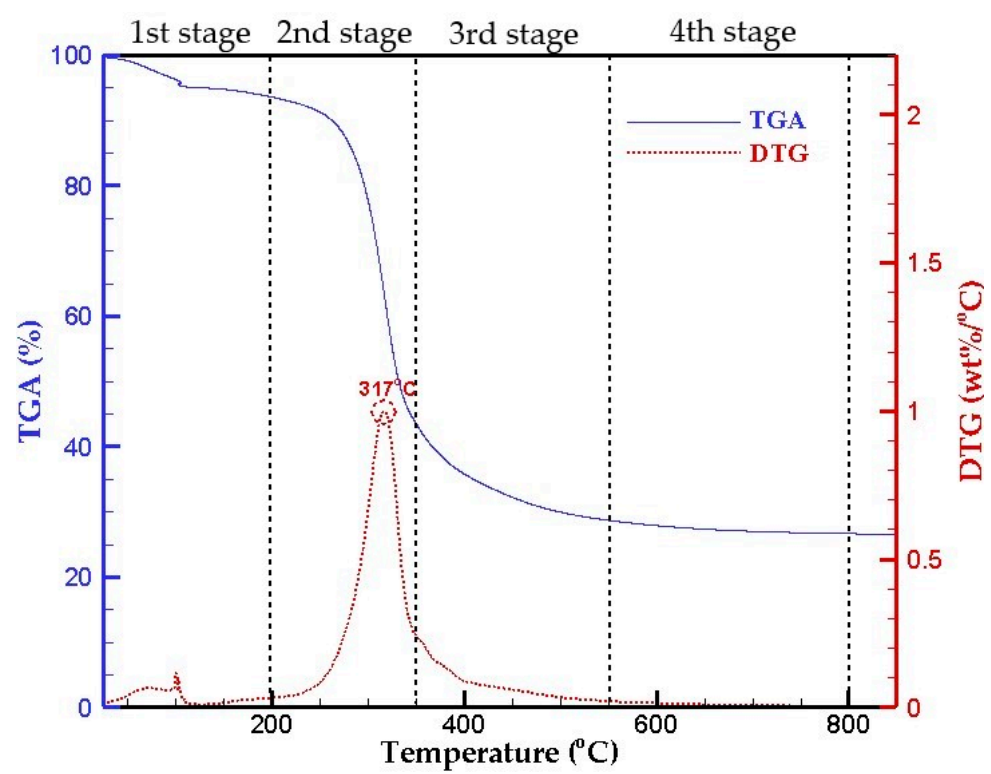

Figure 2. Distributions of thermogravimetric analysis (TGA) and derivative thermogravimetric (DTG) curves of sorghum distilled residue (SDR) in 4 different stages of pyrolysis at a heating rate of $20{ }^{\circ} \mathrm{C} / \mathrm{min}$ in nitrogen. (1st stage: dehydration; 2nd stage: decomposition of proteins and carbohydrates; 3rd stage: decomposition of lipids; and 4th stage: decomposition of other components).

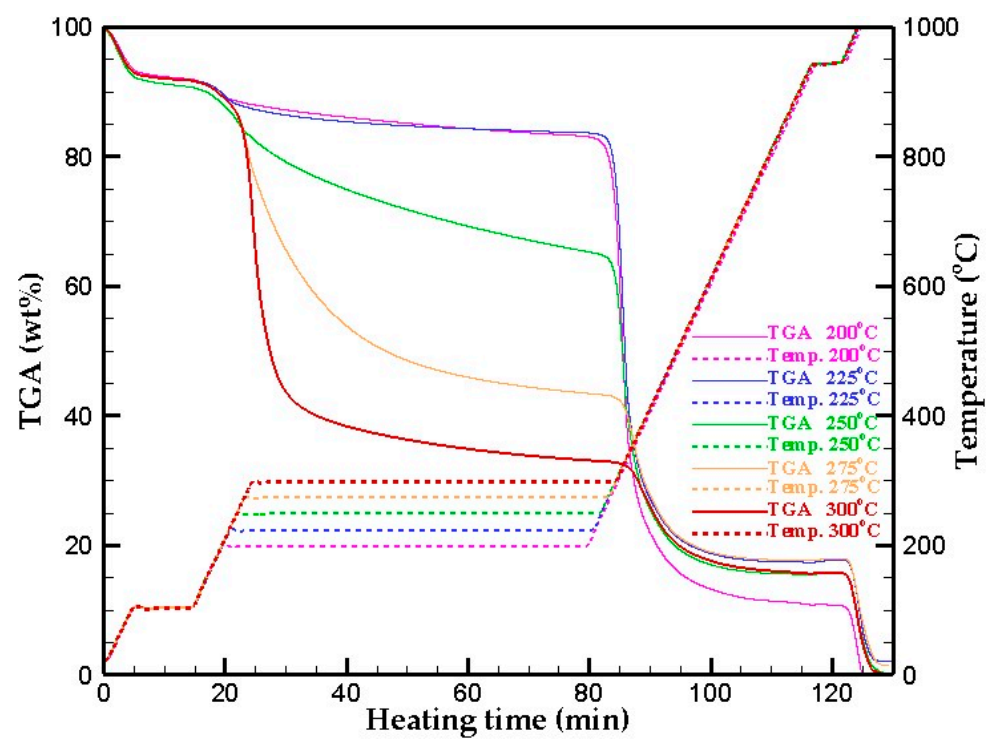

Figure 3. Distributions of thermogravimetric analysis (TGA) and heating temperature curves of 5 different torrefaction temperatures $\left(200,225,250,275\right.$, and $300^{\circ} \mathrm{C}$ of SDR).

In Figure 3, the isothermal torrefaction started at the point when the temperature reached $200,225,250,275$, or $300{ }^{\circ} \mathrm{C}$. Then, these five temperatures were held for $60 \mathrm{~min}$ to isothermally torrefy the SDR. Figure 4 graphs only the data for the $60 \mathrm{~min}$ isothermal period and plots the weight loss increment against the torrefaction time. For the torrefaction temperature below $225^{\circ} \mathrm{C}$, as the temperature time, the weight loss is not significant. For the medium-temperature torrefaction, i.e., 250 and $275^{\circ} \mathrm{C}$, obviously, the longer the torrefaction time is, the greater the weight loss. For the case of $300{ }^{\circ} \mathrm{C}$, the weight loss increases sharply in the beginning, which indicates that most of the thermal decomposition occurs in the beginning and within a short time. 


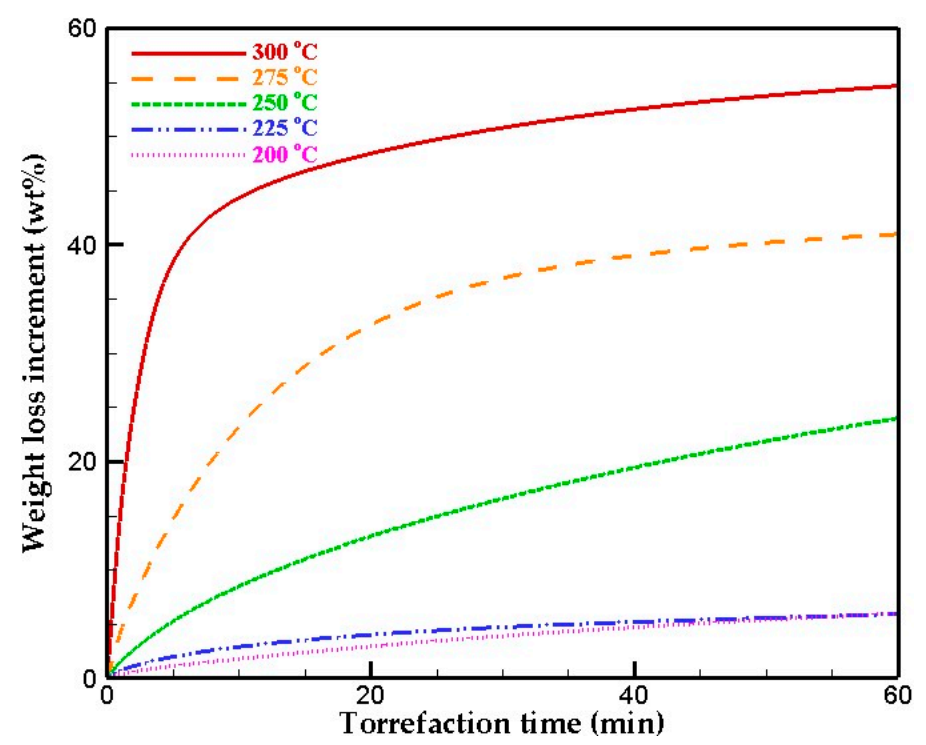

Figure 4. Distributions of weight loss increment of SDR.

Torrefaction severity index (TSI) is a dimensionless parameter [3], which was developed to account for the degree of torrefaction. The definition of TSI is given by Equation (16).

$$
\mathrm{TSI}=\frac{\Delta \mathrm{WI}}{\Delta \mathrm{WI}_{\max }}
$$

where $\Delta \mathrm{WI}$ stands for the weight loss increment at a certain temperature and duration; $\Delta \mathrm{WI}_{\max }$ is the weight loss increment at $300^{\circ} \mathrm{C}$ for $1 \mathrm{~h}$.

By plotting TSI, torrefaction time, and temperature, a three-dimensional diagram can be obtained as shown in Figure 5. From this three-dimensional profile, it can be pointed out that when torrefaction at the temperature below $225^{\circ} \mathrm{C}$, SDR has only a small degree of thermal decomposition. At medium temperature, TSI is relatively sensitive to the duration, so it is not quite suitable for quality control of biochar. For torrefaction at $300^{\circ} \mathrm{C}$, however, the TSI value could exceed 0.8 within $10 \mathrm{~min}$. The 3D graph of TSI-temperature-duration can be used as a useful tool for SDR upgrading to biochar through torrefaction. For example, if the criterion of TSI for biochar is 0.8 , the recommended operating conditions would be $300{ }^{\circ} \mathrm{C}$ and $10-15 \mathrm{~min}$. Therefore, the unstable biochar quality caused by the sensitive curve in the first $10 \mathrm{~min}$ can be avoided and the energy cost can be reduced by ending up the process in about $15 \mathrm{~min}$.

\subsection{Torrefaction Kinetics from the Traditional Model-Free Approach}

The experimental data obtained from five different isothermal torrefaction conditions can be brought into Equation (3) to obtain the rate constant $k$. Afterward, $\ln (\mathrm{k})$ is plotted against $1 / T$ and the coefficient of determination $\left(R^{2}\right)$ of each $n$ can be obtained, as shown in Table 2 . When $n$ is equal to $3, R^{2}$ reaches a maximum, and thereby the best regression line is obtained. In the case of $n=3$, Ea and A can be obtained from the slope and intercept of the straight line in Figure 6. A list of the important kinetics parameters of the torrefaction reaction of SDR in the range of $200-300{ }^{\circ} \mathrm{C}$ is detailed in Table 3 .

To evaluate the traditional model-free approach, these optimal kinetics parameters were brought into Equation (3) $(n=3)$ to obtain the optimal weight loss curves, to compare with the actual curves (Figure 7). It shows that the curve predicted by model-free kinetics is not very consistent with the actual TGA curve. In addition, the fit qualities of five different temperatures are in the range between 92 and $97 \%$. 


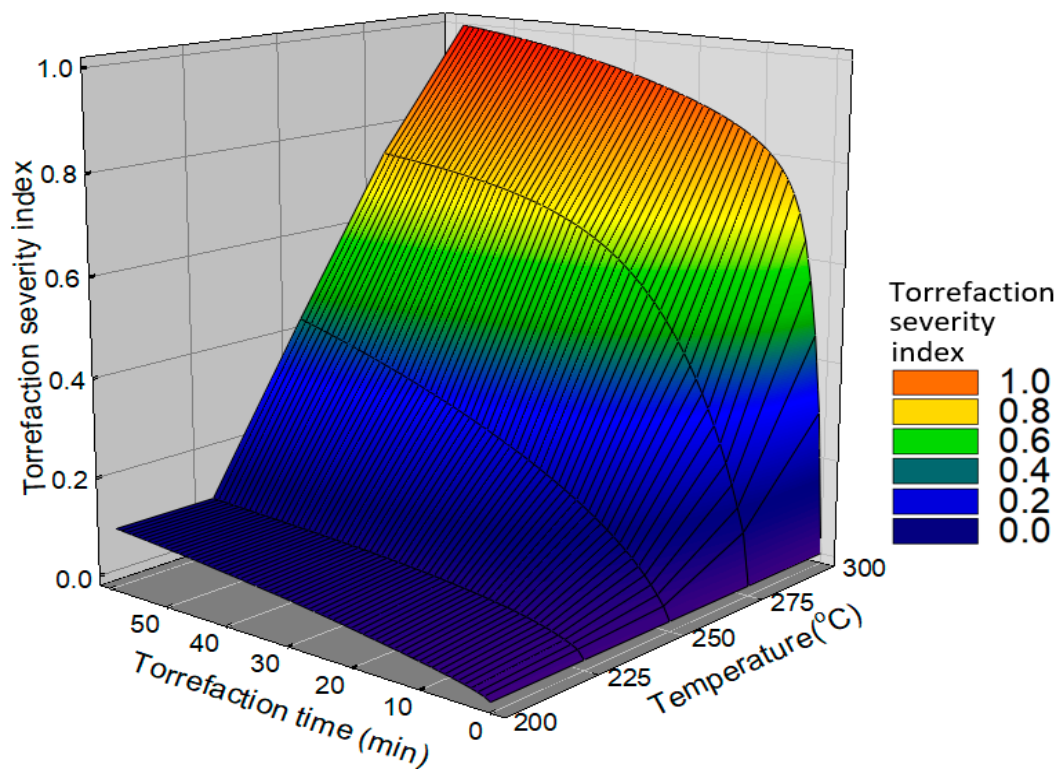

Figure 5. Three-dimensional diagram of torrefaction severity index (TSI) of SDR.

Table 2. Coefficient of determination $\left(\mathrm{R}^{2}\right)$ of the isothermal kinetics of SDR.

\begin{tabular}{ccc}
\hline $\mathbf{n}$ & $\mathbf{R}^{\mathbf{2}}$ \\
\hline 1 & 0.8469 \\
2 & 0.8931 \\
3 & 0.9115 (Max.) \\
4 & 0.9083 \\
5 & 0.9062 \\
6 & 0.9012 \\
7 & 0.8975 \\
8 & 0.8938 \\
9 & 0.8909 \\
\hline
\end{tabular}

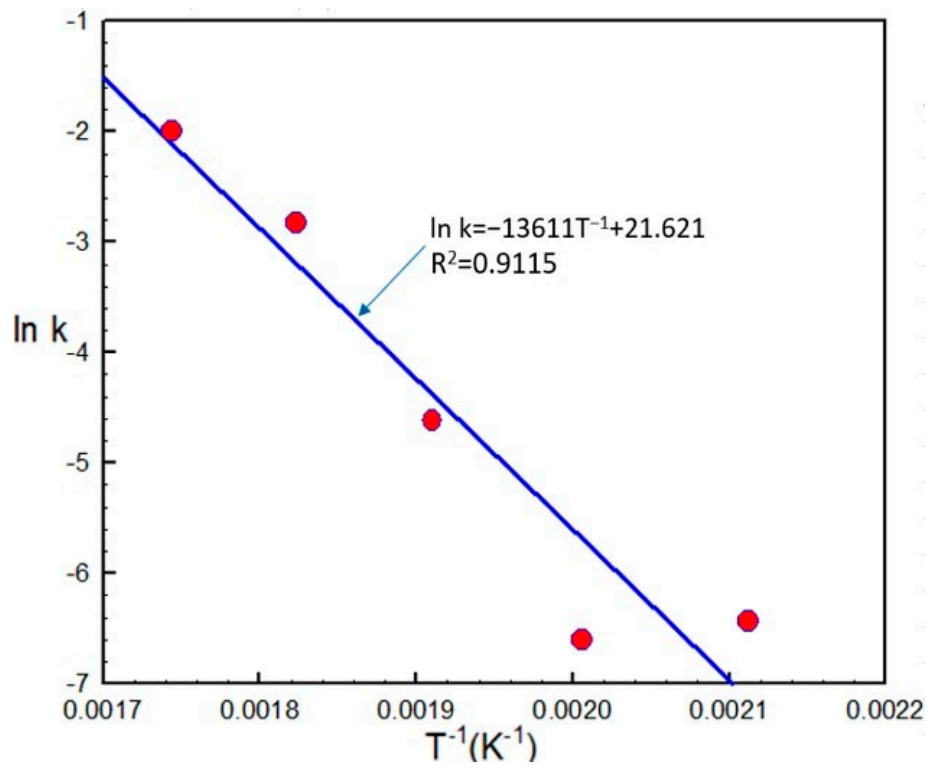

Figure 6. Linear regression of the isothermal kinetics $(n=3)$ of SDR. 
Table 3. The regression line and kinetics parameters of the thermal decomposition of SDR.

\begin{tabular}{cc}
\hline Parameters/Equation & Amount/Expression \\
\hline $\mathrm{R}^{2}$ & 0.9115 \\
Regression line & $\ln \mathrm{k}=-13,611 / \mathrm{T}+21.621$ \\
$\mathrm{n}$ & 3 \\
$\mathrm{Ea}\left(\mathrm{kJ} \cdot \mathrm{mol}^{-1}\right)$ & 113.1619 \\
$\mathrm{~A}\left(\mathrm{~min}^{-1}\right)$ & $2,454,036,361$ \\
\hline
\end{tabular}

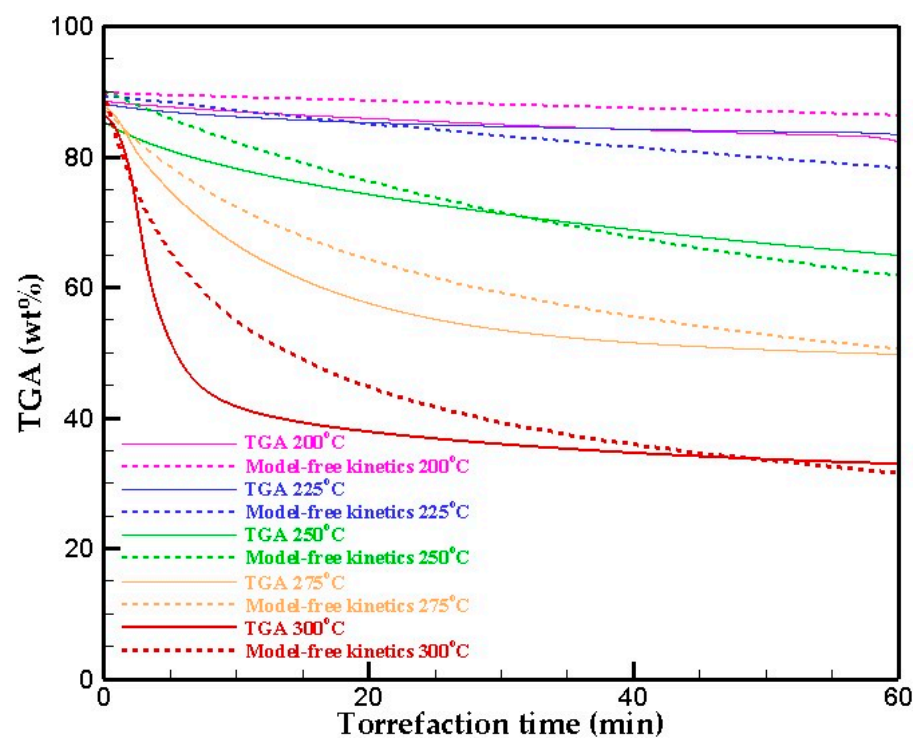

Figure 7. Experimental TGA curve (solid line) and model-free kinetics curve (dotted line) of SDR.

\subsection{Torrefaction Kinetics from PSO Approach}

In this section, a two-step reaction mechanism, shown in Equation (6), was adopted and it was assumed that each step was a first-order reaction. The weight loss curves during the isothermal torrefaction process were simulated with the PSO approach and the results are plotted in Figure 8. From the figure, it is clear that the simulated weight-loss curves and the experimental weight-loss curves are very close to each other. That is, they almost overlap and have very high fit qualities (>99.25). The fit qualities of each temperature are listed in Table 4, while Table 5 details the kinetic parameters at each temperature.

PSO approach was further adopted to simulate the weight change of each component in the two-step reaction mechanism and the results are shown in Figure 9, where reactant A represents SDR; reaction intermediate I represents the partially reacted SDR; product B represents the biochar after SDR upgrading; V1 and V2 represent two volatiles in step 1 and step 2 of the mechanism, respectively. The sum of curves A, I and B is equal to the simulation curve.

Comparing the Figure 9a,b, their total solid weight distributions (the sum of A, I, and B) are very similar, where the $225^{\circ} \mathrm{C}$ case has a higher final biochar $\mathrm{B}$, yet a smaller amount of the partial-reacted SDR (i.e., I). This could be attributed to a relatively higher extent of reaction due to the higher temperature. Figure $9 \mathrm{c}$ indicates that the amount of intermediate I, representing the partial-reacted SDR, is almost unchanged at a high level, which is similar to the curves I at $200{ }^{\circ} \mathrm{C}$ and $225^{\circ} \mathrm{C}$. However, the amounts of V1 and V2 are higher than those two low-temperature curves, so they decrease the final amount of biochar B. Comparing Figure $9 \mathrm{~d}, \mathrm{e}$, the higher temperature of $300^{\circ} \mathrm{C}$ make the reaction of step 1 completed, producing a large amount of gas V1 and intermediate solid I. Meanwhile, the reaction in step 2 is gentler and produces less biochar B. In the case of $275{ }^{\circ} \mathrm{C}$, the temperature is milder than $300^{\circ} \mathrm{C}$. Step 2 fully reacts, so that curve I drops at the initial stage of the reaction and a large amount of intermediate I is continuously converted into 
biochar $\mathrm{B}$. Therefore, as far as the quality of SDR is concerned, the operating temperature of $275^{\circ} \mathrm{C}$ is the best, because biochar B is very high (about $60 \%$ ) and intermediate I that has not been upgraded is very little (about $2 \%$ ).

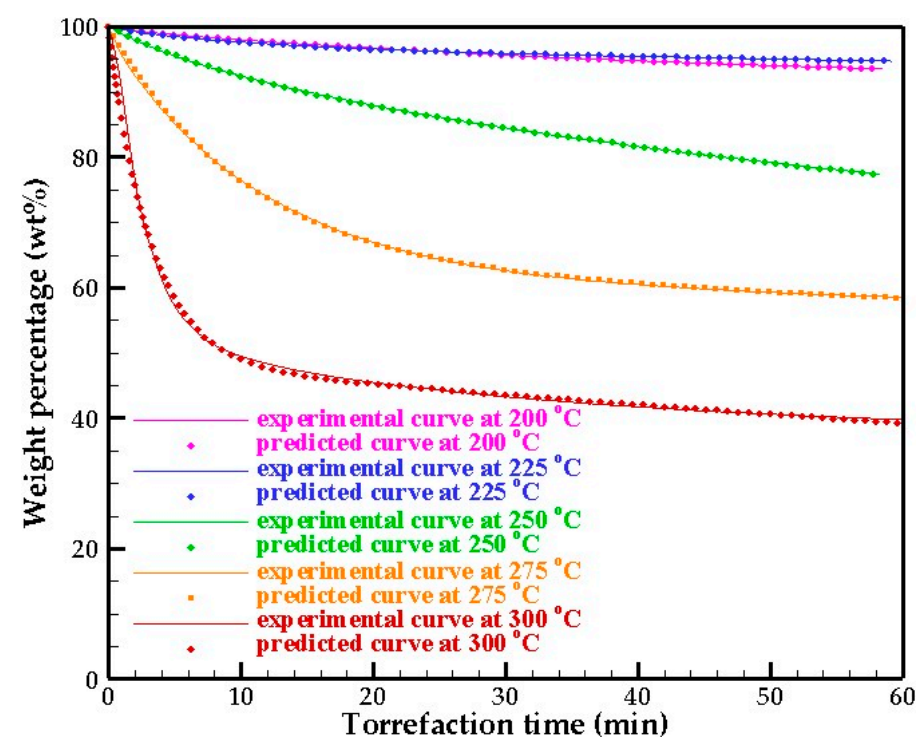

Figure 8. Experimental TGA curve (solid line) and PSO-simulated curve (dotted line) of SDR.

Table 4. Fit quality for each temperature of SDR.

\begin{tabular}{cc}
\hline Temperature $\left({ }^{\circ} \mathbf{C}\right)$ & Fit Quality, F (\%) \\
\hline 200 & 99.98 \\
225 & 99.97 \\
250 & 99.91 \\
275 & 99.77 \\
300 & 99.28 \\
\hline
\end{tabular}

Table 5. Kinetic parameters at each temperature.

\begin{tabular}{ccccc}
\hline Parameters & $\mathbf{k}_{\mathbf{1}}$ & $\mathbf{k}_{\mathbf{V} \mathbf{1}}$ & $\mathbf{k}_{\mathbf{2}}$ & $\mathbf{k}_{\mathbf{V} \mathbf{2}}$ \\
\hline $200^{\circ} \mathrm{C}$ & & & & \\
$\mathrm{Ea}$ & $4.21 \times 10^{4}$ & $3.88 \times 10^{4}$ & $1.67 \times 10^{5}$ & $9.27 \times 10^{4}$ \\
$\mathrm{~A}$ & $2.42 \times 10^{2}$ & 1.05 & $8.13 \times 10^{14}$ & $4.45 \times 10^{5}$ \\
$\mathrm{k}$ & $5.41 \times 10^{-3}$ & $5.49 \times 10^{-5}$ & $2.65 \times 10^{-4}$ & $2.57 \times 10^{-5}$ \\
$225^{\circ} \mathrm{C}$ & & & & \\
$\mathrm{Ea}$ & $4.52 \times 10^{4}$ & $4.04 \times 10^{4}$ & $1.75 \times 10^{5}$ & $9.83 \times 10^{4}$ \\
$\mathrm{~A}$ & $1.45 \times 10^{2}$ & 1.09 & $8.50 \times 10^{14}$ & $3.23 \times 10^{5}$ \\
$\mathrm{k}$ & $2.64 \times 10^{-3}$ & $6.41 \times 10^{-5}$ & $3.72 \times 10^{-4}$ & $1.59 \times 10^{-5}$ \\
$250^{\circ} \mathrm{C}$ & & & & \\
$\mathrm{Ea}$ & $4.53 \times 10^{4}$ & $3.69 \times 10^{4}$ & $1.86 \times 10^{5}$ & $9.56 \times 10^{4}$ \\
$\mathrm{~A}$ & $8.43 \times 10$ & $8.78 \times 10^{-1}$ & $6.49 \times 10^{14}$ & $2.78 \times 10^{5}$ \\
$\mathrm{k}$ & $2.54 \times 10^{-3}$ & $1.83 \times 10^{-4}$ & $1.80 \times 10^{-4}$ & $7.93 \times 10^{-5}$ \\
$275^{\circ} \mathrm{C}$ & & & & \\
$\mathrm{Ea}$ & $5.21 \times 10^{4}$ & $3.24 \times 10^{4}$ & $1.89 \times 10^{5}$ & $9.43 \times 10^{4}$ \\
$\mathrm{~A}$ & $2.63 \times 10^{2}$ & $8.10 \times 10^{-1}$ & $9.07 \times 10^{14}$ & $3.07 \times 10^{5}$ \\
$\mathrm{k}$ & $2.85 \times 10^{-3}$ & $6.65 \times 10^{-4}$ & $7.84 \times 10^{-4}$ & $3.13 \times 10^{-4}$ \\
$30{ }^{\circ} \mathrm{C}$ & & & \\
$\mathrm{Ea}$ & $5.17 \times 10^{4}$ & $3.00 \times 10^{4}$ & $2.02 \times 10^{5}$ & $1.03 \times 10^{5}$ \\
$\mathrm{~A}$ & $1.38 \times 10^{2}$ & 1.50 & $6.15 \times 10^{14}$ & $2.25 \times 10^{5}$ \\
$\mathrm{k}$ & $2.68 \times 10^{-3}$ & $2.77 \times 10^{-3}$ & $2.22 \times 10^{-4}$ & $9.31 \times 10^{-5}$ \\
\hline
\end{tabular}



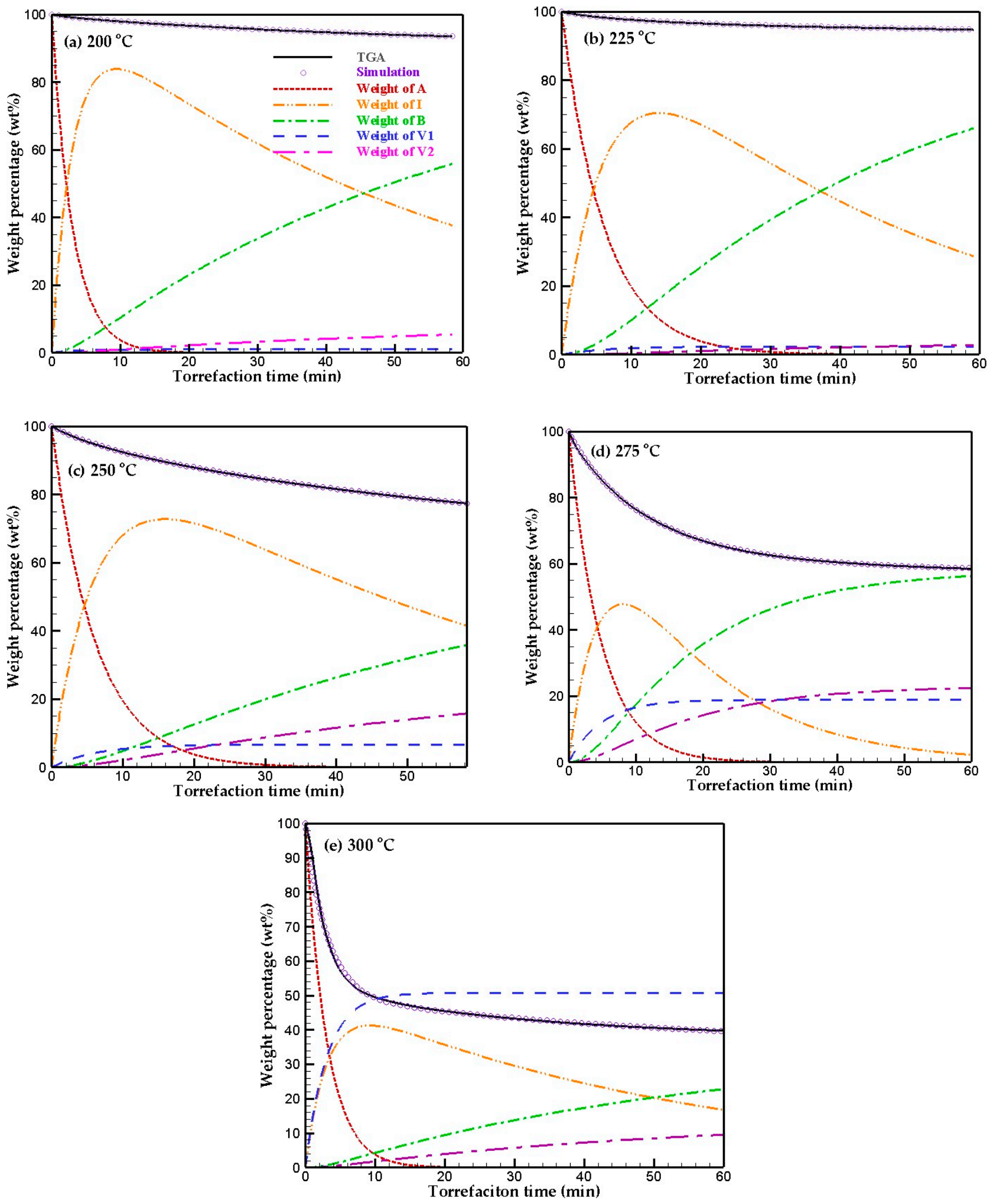

Figure 9. Weight distribution of each component over torrefaction time at (a) 200, (b) 225, (c) 250, (d) 275 and (e) $300{ }^{\circ} \mathrm{C}$.

\section{Conclusions}

The results of composition analysis show that SDR remains a lot of carbohydrates and proteins that are not utilized by microorganisms. Therefore, in the TGA diagram, a violent thermal decomposition occurs around $317^{\circ} \mathrm{C}$. This could be attributed to the reactions of depolymerization, decarboxylation, and cracking of carbohydrates and proteins. The 
3D TSI is a useful reference tool for upgrading SDR to biochar. The analysis reveals that the torrefaction should be held at $300^{\circ} \mathrm{C}$ for $10-15 \mathrm{~min}$ to avoid the difficulty of quality control of biochar caused by the sensitive curve in the first $10 \mathrm{~min}$ and to reduce the energy cost by ending up the process in $15 \mathrm{~min}$. In the Arrhenius equation, Ea and A can be regarded as constants only on an important assumption that the reaction takes place in a situation where the "reaction temperature is a constant". The optimal parameters obtained by the conventional kinetic approach can not accurately predict the torrefaction behavior and the fit qualities are at a relatively low level of $92-97 \%$. However, the PSO algorithm can accurately simulate the real torrefaction behavior, all the fit qualities are higher than $99 \%$. PSO algorithm is not only superior to the traditional Arrhenius equation in terms of kinetics behavior approach, it can also be further adopted to simulate the weight change distribution curves of each component in the two-step reaction mechanism. For example, the results from Table 5 show that $\mathrm{k}_{\mathrm{V} 1}$ increases with increasing temperature. Therefore, Figure 9a-e shows that V1 increases significantly with increasing temperature. When the torrefaction temperature reaches $300{ }^{\circ} \mathrm{C}$, half of the SDR converted into gas phase V1, so that product $\mathrm{B}$ is at a low level of $22 \%$. Another example is that the results in Table 5 show that the maximum value of $\mathrm{k}_{2}$ appears at $275^{\circ} \mathrm{C}$, so a large amount of impure intermediate I is converted into product B. Figure $9 \mathrm{~d}$ shows that I is only $2 \%$ at $275^{\circ} \mathrm{C}$. If higher biochar quality is required, the operating temperature of $275^{\circ} \mathrm{C}$ is better than $300^{\circ} \mathrm{C}$, because the reaction in step 2 is relatively complete, the final SDR-biochar has a high product $\mathrm{B}$ yield and a low partial-reacted intermediate I content. This study shows that the PSO algorithm is a promising tool that can be used to accurately predict the torrefaction kinetics and even predict reaction intermediates that affect product quality.

Author Contributions: S.-W.Y. performed the experiments, analyzed data and wrote the paper. W.-H.C. created the research concept, organized the work, designed the experiments, analyzed data and provided facilities and instruments for the research. J.-S.C. provided advice and research strategy. C.-F.E. assisted in operating the PSO simulation program. S.R.N. analyzed data. P.L.S. analyzed data. All authors have read and agreed to the published version of the manuscript.

Funding: This research was funded by the Ministry of Science and Technology, Taiwan, R.O.C., under the contracts MOST 109-2221-E-006-040-MY3 and MOST 109-3116-F-006-016-CC1.

Institutional Review Board Statement: Not applicable.

Informed Consent Statement: Not applicable.

Data Availability Statement: Not applicable.

Acknowledgments: The authors acknowledge the financial support of the Ministry of Science and Technology, Taiwan, R.O.C., under the contracts MOST 109-2221-E-006-040-MY3 and MOST 109-3116F-006-016-CC1 for this research.

Conflicts of Interest: The authors declare no conflict of interest.

\section{References}

1. Adeleke, A.A.; Odusote, J.K.; Ikubanni, P.P.; Lasode, O.A.; Malathi, M.; Paswan, D. Essential basics on biomass torrefaction, densification and utilization. Int. J. Energy Res. 2020, 45, 1375-1395. [CrossRef]

2. Chen, W.-H.; Lin, B.-J.; Lin, Y.-Y.; Chu, Y.-S.; Ubando, A.T.; Show, P.L.; Ong, H.C.; Chang, J.-S.; Ho, S.-H.; Culaba, A.B.; et al. Progress in biomass torrefaction: Principles, applications and challenges. Prog. Energy Combust. Sci. 2021, 82, 100887. [CrossRef]

3. Chen, W.H.; Huang, M.Y.; Chang, J.S.; Chen, C.Y. Thermal decomposition dynamics and severity of microalgae residues in torrefaction. Bioresour. Technol. 2014, 169, 258-264. [CrossRef] [PubMed]

4. Chen, W.H.; Lu, K.M.; Tsai, C.M. An experimental analysis on property and structure variations of agricultural wastes undergoing torrefaction. Appl. Energy 2012, 100, 318-325. [CrossRef]

5. Lu, K.-M.; Lee, W.-J.; Chen, W.-H.; Lin, T.-C. Thermogravimetric analysis and kinetics of co-pyrolysis of raw/torrefied wood and coal blends. Appl. Energy 2013, 105, 57-65. [CrossRef]

6. Prins, M.J.; Ptasinski, K.J.; Janssen, F.J.J.G. Torrefaction of wood. J. Anal. Appl. Pyrolysis 2006, 77, 28-34. [CrossRef]

7. Rousset, P.; Aguiar, C.; Labbe, N.; Commandre, J.M. Enhancing the combustible properties of bamboo by torrefaction. Bioresour. Technol. 2011, 102, 8225-8231. [CrossRef] 
8. Chen, Y.-D.; Liu, F.; Ren, N.-Q.; Ho, S.-H. Revolutions in algal biochar for different applications: State-of-the-art techniques and future scenarios. Chin. Chem. Lett. 2020, 31, 2591-2602. [CrossRef]

9. Li, Y.H.; Kuo, W.C. The study of optimal parameters of oxygen-enriched combustion in fluidized bed with optimal torrefied woody waste. Int. J. Energy Res. 2020, 44, 7416-7434. [CrossRef]

10. Chen, C.Y.; Chen, W.H. Co-torrefaction followed by co-combustion of intermediate waste epoxy resins and woody biomass in the form of mini-pellet. Int. J. Energy Res. 2020, 44, 9317-9332. [CrossRef]

11. Ubando, A.T.; Felix, C.B.; Chen, W.H. Biorefineries in circular bioeconomy: A comprehensive review. Bioresour. Technol. 2020, 299, 122585. [CrossRef]

12. Wang, T.T.; Sun, Z.Y.; Huang, Y.L.; Tan, L.; Tang, Y.Q.; Kida, K. Biogas Production from Distilled Grain Waste by Thermophilic Dry Anaerobic Digestion: Pretreatment of Feedstock and Dynamics of Microbial Community. Appl. Biochem. Biotechnol. 2018, 184, 685-702. [CrossRef]

13. Luo, T.; Huang, H.; Mei, Z.; Shen, F.; Ge, Y.; Hu, G.; Meng, X. Hydrothermal pretreatment of rice straw at relatively lower temperature to improve biogas production via anaerobic digestion. Chin. Chem. Lett. 2019, 30, 1219-1223. [CrossRef]

14. Su, M.Y.; Tzeng, W.S.; Shyu, Y.T. An analysis of feasibility of bioethanol production from Taiwan sorghum liquor waste. Bioresour. Technol. 2010, 101, 6669-6675. [CrossRef] [PubMed]

15. Ye, G.; Luo, H.; Ren, Z.; Ahmad, M.S.; Liu, C.-G.; Tawab, A.; Al-Ghafari, A.B.; Omar, U.; Gull, M.; Mehmood, M.A. Evaluating the bioenergy potential of Chinese Liquor-industry waste through pyrolysis, thermogravimetric, kinetics and evolved gas analyses. Energy Convers. Manag. 2018, 163, 13-21. [CrossRef]

16. Chen, W.-H.; Peng, J.; Bi, X.T. A state-of-the-art review of biomass torrefaction, densification and applications. Renew. Sustain. Energy Rev. 2015, 44, 847-866. [CrossRef]

17. Devos, P.; Commandre, J.M.; Brancheriau, L.; Candelier, K.; Rousset, P. Modeling mass loss of biomass by NIR-spectrometry during the torrefaction process. Int. J. Energy Res. 2020, 44, 9787-9797. [CrossRef]

18. Bach, Q.V.; Chen, W.H.; Chu, Y.S.; Skreiberg, O. Predictions of biochar yield and elemental composition during torrefaction of forest residues. Bioresour. Technol. 2016, 215, 239-246. [CrossRef]

19. Chew, J.J.; Doshi, V. Recent advances in biomass pretreatment-Torrefaction fundamentals and technology. Renew. Sustain. Energy Rev. 2011, 15, 4212-4222. [CrossRef]

20. Ciolkosz, D.; Wallace, R. A review of torrefaction for bioenergy feedstock production. Biofuels Bioprod. Biorefining 2011, 5, 317-329. [CrossRef]

21. Van der Stelt, M.J.C.; Gerhauser, H.; Kiel, J.H.A.; Ptasinski, K.J. Biomass upgrading by torrefaction for the production of biofuels: A review. Biomass Bioenergy 2011, 35, 3748-3762. [CrossRef]

22. Chen, W.-H.; Chu, Y.-S.; Liu, J.-L.; Chang, J.-S. Thermal degradation of carbohydrates, proteins and lipids in microalgae analyzed by evolutionary computation. Energy Convers. Manag. 2018, 160, 209-219. [CrossRef]

23. Chen, W.-H.; Eng, C.F.; Lin, Y.-Y.; Bach, Q.-V. Independent parallel pyrolysis kinetics of cellulose, hemicelluloses and lignin at various heating rates analyzed by evolutionary computation. Energy Convers. Manag. 2020, 221, 113165. [CrossRef]

24. Chen, W.-H.; Kuo, P.-C. Isothermal torrefaction kinetics of hemicellulose, cellulose, lignin and xylan using thermogravimetric analysis. Energy 2011, 36, 6451-6460. [CrossRef]

25. Aquilanti, V.; Mundim, K.C.; Cavalli, S.; De Fazio, D.; Aguilar, A.; Lucas, J.M. Exact activation energies and phenomenological description of quantum tunneling for model potential energy surfaces. The $\mathrm{F}+\mathrm{H} 2$ reaction at low temperature. Chem. Phys. 2012, 398, 186-191. [CrossRef]

26. Liu, J.-L.; Lin, J.-H. Evolutionary computation of unconstrained and constrained problems using a novel momentum-type particle swarm optimization. Eng. Optim. 2007, 39, 287-305. [CrossRef]

27. Rizzo, A.M.; Prussi, M.; Bettucci, L.; Libelli, I.M.; Chiaramonti, D. Characterization of microalga Chlorella as a fuel and its thermogravimetric behavior. Appl. Energy 2013, 102, 24-31. [CrossRef]

28. Peng, W.M.; Wu, Q.Y.; Tu, P.G.; Zhao, N.M. Pyrolytic characteristics of microalgae as renewable energy source determined by thermogravimetric analysis. Bioresour. Technol. 2001, 80,1-7. [CrossRef]

29. Peng, W.M.; Wu, Q.Y.; Tu, P.G. Pyrolytic characteristics of heterotrophic Chlorella protothecoides for renewable bio-fuel production. J. Appl. Phycol. 2001, 13, 5-12. [CrossRef] 